\title{
ANALISIS PEMAKAIAN PARTIKEL NI DALAM KALIMAT BAHASA JEPANG PADA BUKU MINNA NO NIHONGO I DAN II
}

\section{Kliwon Sahudi}

Sekolah Tinggi Bahasa Asing Cipto Hadi Pranoto

Email: kliwonsahudi17@gmail.com

\begin{abstract}
For good interaction between the two parties to establish communication, procedures and rules are needed. How to arrange a sentence so that its purpose and purpose can be understood. Japanese grammar is not only able to arrange a sentence with the existence of subjects, predicates, objects, and information. There is another element that is needed to arrange a sentence, namely particles. This article belongs to the kakujoshi word class, that is, the particle that follows the noun and shows the relationship between the word and the next word, this article has a meaning, which is: 'di, but has a variety of useful functions. Therefore the purpose of this study is to determine the function of the use of these particles in Japanese sentences in various contexts, accurately and correctly both oral and written. The method used in this research is descriptive method with literature study method. This research was analyzed through three stages namely, data collection, data analysis, and decision making. The results of this study illustrate that the function of using these particles to state the place of existence of an object, time, opponent, and destination contained in the data source.
\end{abstract}

Keywords: Usage, Particles, $\mathrm{Ni}$

\begin{abstract}
Abstrak
Agar terciptanya interaksi dengan baik antara kedua pihak yang menjalin komunikasi, maka diperlukan tata cara dan aturan. Bagaimana menyusun suatu kalimat itu sehingga dapat dimengerti maksud dan tujuannya. Gramatika bahasa Jepang tidak hanya bisa menyusun suatu kalimat dengan adanya subjek, predikat, objek dan keterangan. Ada unsur lain yang diperlukan untuk menyusun suatu kalimat yaitu partikel. Partikel ni masuk kelas kata kakujoshi yaitu, partikel yang mengikuti kata benda dan menunjukkan hubungan antara kata itu dengan kata berikutnya partikel ni mempunyai arti yaitu: 'di”, namun mempunyai berbagai macam fungsi pemakainya. Oleh karena itu tujuan penelitian ini untuk mengetahui fungsi pekakaian partikel ni dalam kalimat bahasa Jepang diberbagai konteks, secara tepat dan benar baik lisan dan tulisan. Metode yang digunakan dalam penelitian ini merupakan metode deskriptif dengan metode studi kepustakaan. Penelitian ini dianalis melalui tiga tahap yaitu, pengumpulan data, analisis data, dan pengambilan keputusan. Hasil dari penelitian ini mengambarkan bahwa fungsi pemakaian partikel ni untuk menyatakan tempat keberadaan suatu benda,waktu, lawan,dan tujuan yang terdapat pada sumber data.
\end{abstract}


Kata kunci : Pemakaian, Partikel, Ni

\section{Pendahuluan}

Bahasa merupakan alat komunikasi yang paling esensial dalam kehidupan manusia. Tanpa adanya bahasa manusia tidak dapat berinteraksi dengan baik terhadap sesamanya dan lingkungan sekitarnya (Herniti, 2010). Bahasa pada umumnya terbagi menjadi tiga jenis yaitu bahasa lisan, bahasa tulisan, dan bahasa isyarat (Aisah \& Noviadi, 2018). Bahasa lisan merupakan jenis bahasa yang paling sering digunakan untuk komunikasi atau mendokumentasikan informasi (Aisyah, Kalijaga, \& Guna, 2016), sedangkan bahasa isyarat adalah jenis Bahasa diciptakan dalam suatu kondisi tertentu (Kartika, 2018).

Definisi bahasa sendiri sebagaimana dikutip dari Encyclopedia American yaitu sebagai sistim sembol vocal yang merupakan alat interaksi antara satu atau lebih lapisan masyarakat (Filliyani, 2003). Bahasa merupakan alat komunikasi yang sangat penting bagi kehidupan manusia, karena semua kegiatan yang dilakukan oleh manusia selalu menggunakan Bahasa (Cahyaningrum, 2019). Bahasa mempunyai aneka sifat di antaranya sifat dinamis. Hal ini berkaitan erat dengan penggunaan Bahasa yaitu manusia yang selalu mengalami perkembangan dari waktu ke waktu (Haraha \& Pi, 2018). Seiring perkembangan ilmu pengetahuan terciptalah istilah-istilah baru yang memiliki pemikiran, pendapat dan teori-teori yang bermula dari bahasa itu sendiri. Karena dengan bahasa manusia dapat mengungkapkan dan mengekpresikan pendapat dan fikirannya.

Dalam Kamus Besar Bahasa Indonesia dijelaskan bahwa bahasa adalah sistim lambing bunyi berartikulasi (yang dihasilkan oleh alat-alat ucap) yang bersifat sewenang-wenang dan konvensional yang dipakai sebagai alat komunikasi untuk menyatakan perasaan dan fikiran (Depdikbud, 1990). Oleh karena itu, untuk menyatakan perasaan dan fikiran, digunakanlah alat komunikasi seperti bahasa.

Agar tercipta suatu interaksi antara kedua belah pihak yang menjalin hubungan maka diperlukan sebuah bahasa sebagai alat komunikasi dengan tata cara dan aturanaturan berbahasa. Aturan dan tata cara bahasa disebut gramatika. Dengan mempelajari gramatika kita akan mengetahui bagaimana menyusun suatu kalimat itu dapat dimengerti maksud dan tujuan kalimat tersebut. Dalam gramatika bahasa Jepang kita tidak hanya bisa menyusun suatu kalimat dengan adanya subjek, predikat, objek serta keterangan. Ada unsur lainnya yang diperlukan dalam menyusun suatu kaliamat bahasa Jepang yaitu Partikel. Secara harfiah partikel dapat diartikan sebagai kata bantu, postposisi atau partikel (Sudjianto, 1996).

Partikel dalam bahasa Jepang banyak ragamnya dan mempunyai peranan yang penting di dalam tata bahasa Jepang. Selain itu pertikel juga memberikan ciri khas atau karakteristik tersendiri. Partikel tidak dapat berdiri sendiri tetapi selalu menempel pada kata yang ada di depannya. Banyaknya partikel yang dipergunakan dalam bahasa Jepang dan masing-masing menunjukkan fungsinya, maka partikel-partikel bahasa Jepang merupakan salah satu kelas kata yang di dalam bahasa Jepang. Partikel dalam bahasa Jepang disebut "Joshi". Untuk memakai partikel dengan benar bukanlah suatu 
hal yang mudah. Karena partikel dalam bahasa Jepang tidak dapat dicocok-cocokkan atau dipadan-padankan begitu saja,karena penempatan partikel dengan benar menjadi keharusan dalam setiap tingkatan pembicaraan bahasa Jepang. Sebagai kesatuan yang berdiri sendiri, partikel tidak mempunyai arti. Sebuah partikel mungkin dapat didefinisikan sebagai bagian yang tak dapat ditafsirkan dalam sebuah percakapan, memiliki kemutlakan arti tersendiri yang bebas terikatan, melengkapi dirinya sendiri dalam bagian-bagian pembicaraan, ia menempatkan dirinya dalam konteks. Dari sekian banyak partikel Bahasa Jepang, partikel NI adalah contoh partikel yang sering di jumpai dalam pembentukan sebuah kalimat dan merupakan partikel yang mempunyai Bermacam-macam fungsi pemakaiannya. Hal ini merupakan kesulitan utama dalam mempelajari ilmu bahasa, khususnya pemakaian partikel NI yang mempunyi bermacammacam fungsi. Sedemikian vitalnya peranan partikel tersebut, maka tentu saja mempunyai aturan-aturan dan kaidah-kaidah tertentu, sehingga kalimat yang dibuat akan bermakna. Dalam penelitian ini penulis mengikutsertakan partikel lain yang mempunyai persamaan arti sebagai pembanding.

\section{彼はベドにねています}

Kare wa bedo ni nete imasu

Dia sedang tidur di tempat tidur.

彼はあのべドでねています

Kare wa bedo de nete imasu

Dia sedang tidur di tempat tidur.

Jika diterjemahkan ke dalam Bahasa Indonesia pemakaian NI dan De menunjukkan tempat yang mempunyai makna gramatikal yang sama yaitu "di". Tetapi bagaimana halnya dalam bahasa Jepang?. Apakah ada perbedaan makna gramatikal. Perbedaan partikel ni dan de pada kalimat di atas dititik beratkan pada cara memandang kalimat tersebut. Partikel ni pada kalimat a dengan pemikiran bahwa dia pada saat itu sedang berada di tempat tidur, sedangkan partikel de pada kalimat b dengan pikiran bahwa dia pada saat itu sedang melakukan aktifitas tidur di tempat tidur (Sudjianto, 2000).

\section{Metode Penelitian}

Secara etimologis metodologi berasal dari methodos dan logos yaitu filsafah atau ilmu mengenai metode (Ratna, 2004). Metode merupakan cara utama yang dipergunakan untuk mencapai tujuan (Surakhmad, 1990). Dalam penelitian ini penulis menggunaka metode deskritif. Penelitian deskriptif merupakan penelitian yang bertujuan untuk mengumpulkan informasi mengenai status suatu gejala yang ada, yaitu gejala yang ada pada saat penelitian dilakukan (Zellatifanny \& Mudjiyanto, 2018). Penelitian ini tidak selalu membutuhkan hipotesis, demikianpula dengan perlakuan atau manipulasi terhadap variable penelitian. Penyelidikan deskriptif tertuju pada pemecahan masalah yang ada pada masa terbatas hanya sampai pada pengumpulan dan penyusunan 
sekarang. Pelaksanaan metode deskriptif tidak data, tetapi meliputi analisa dan interpretasi tentang arti data itu.Karena itulah maka dapat terjadi sebuah penyelidikan deskriptif membandingkan persamaan dan perbedaan fenomena tertentu lalu mengambil studi komperatif, atau mengukur sesuatu dinamis seperti dalam berbagai bentuk studi kualitatif, angket, tes, interview, dan lain-lain atau klasifikasi.

\section{Hasil dan Pembahasan}

Dalam bagian ini dideskripsikan pemakian partikel ni tersebut dari contoh kalimat berdasarkan fungsinya yaitu untuk menyatakan tempat, waktu, lawan, tujuan. Untuk mengetahui fungsi pemakaian partikel ni dalam kalimat dengan benar dan tepat.

A. Untuk menyatakan tempat dimana seseorang /benda berada

\section{机の上に写真があります}

Tsukue no ue ni shashin ga arimasu

Di atas meja ada foto

\section{いすのしたにねこがいます}

Isu no shita ni neko ga imasu

Di bawah kursi ada kucing

\section{ミラーさんは会議室にいます}

Mirasan ha kaigisitsu ni imasu

Tuan Miller ada di ruang rapat

Ternyata dari contok kalimat di atas akan terlihat fungsi pemakaian partikel ni. Dari contoh kalimat a menyatakan keberadaan benda atau benda yang tidak bernyawa yang ditunjukkan oleh topik berada setelah kata keterangan tempat. Predikat berupa kata kerja yaitu "arimasu/aru yang berarti ada. Kemudian dari contoh kalimat $b$ dan $c$ fungsi pemakaian partikel ni menyatakan tempat beradanya benda hidup / orang / hewan atau benda yang bernyawa yang ditunjukkan oleh kata keterangan tempat berupa nomina sebelum partikel ni dan predikat kata kerja imasu / iru yang berarti "ada". Dari kata kerja tersebut di atas maka mengandung makna adanya sesuatu yang membutuhkan tempat atau menempati atau menempati tempat tertentu, seperti kaigisitsu = ruang rapat. Tempat tersebut dinyatakan oleh partikel ni yang menempel/ terletak pada kata - kata yang menyatakan tempat.

B. Untuk menyatakan waktu

Fungsi pemakain partikel ni yang berikutnya setelah kata benda yang menunjukkan waktu, dipakai partikel ni untuk menunjukkan waktu kejadian.Yang dimaksud dengan waktu atau keterangan waktu adalah keterangan yang memumjukkan atau menjelaskan berlangsungnya peristiwa di dalam suatu bidang waktu misalnya: sekarang besok,kemarin dan lainya.

私は朝六時におきます

Watashi ha rokuji ni okimasu

Saya bangun pada jam 6 pagi

\section{三月二十五日に日本へ行きます}


Sangatsu nijugoonichi ni Nihon e ikimasu

Saya datang ke Jepang pada tanggal 25 maret.

私は日曜に国へ帰ります

Watashi ha nichiyoubi ni kuni he karerimasu

Saya akan pulang pada hari minggu

私は日本に一年います

Watashi ha Nihon ni ichinen imasu

Saya tinggal di Jepang selama satu tahun

Dari contoh kalimat di atas mengandung kata keterangan waktu, yang menyatakan waktu terjadinya suatu perbuatan atau kegiatan yang segera selesai. Pada kalimat 1 sampai 3 menunjukkan kata keterangan waktu yang digunakan, kata keterangan waktu tersebut merupakan kata keterangan yang menyatakan waktu yang tepat dan tertentu. Sedangkan kalimat no 4 merupakan lamanya waktu tinggal.

C. Untuk menyatakan lawan

Fungsi partikel ni untuk menyatakan lawan adalah seseorang yang menjadi pihak lawan dari suatu tindakan atau perbuatan. Fungsi pemakaian partikel ni yang menyatakan lawan dapat dibagai menjadi tiga bagin yaitu :

1. Lawan dalam suatu tindakan atau perbuatan

Dalam suatu kegiatan seseorang yang ditunjukan kepadaorang lain atau pihak yang menjadi lawan. Dalam hal ini yang menjadi pihak lawan bisa berupa orang atau benda. Pihak lawan dinyatakan oleh partikel ni yang terletak pada kata - kata tersebut. contohnya :

私は砂糖さんに電話をかけます。

Watashi ha satosan ni denwa wo kakemasu.

Saya menelepon saudara sato.

2. Lawan dalam suatu tindakan atau perbuatan member dan menerima

Kata kerja yang menyatakan seseorang berbuat sesuatu untuk orang lain. Perbuatan itu bisanya berupa jasa maupun bisa berbentuk suatu hal yang nyata yaitu berupa benda/jasa. Dalam hal ini pembicara memberikan suatu perbuatan jasa atau benda kepada orang lain sebagai pihak lawan. Pihak lawan ini merupakan tempat tujuan dari tindakan yang dilakukan. Pihak lawan dinyatakan adanya partikel ni yang terletak pada kata-kata tersebut. Contohnya 私はカリナーさんにチョケレトをもらいます

Watashi ha karina-san ni cokereto o moraimasu

Saya menerima cokelat dari saudari Karina

私はワットーさんに本をかりました

Watashi ha Watto - san ni hon o karimashita

Saya meminjam buku dari saudara Watt.

3. Lawan dalam suatu pernyataan pemberi dan penerima menurut hubungan pelaku 
Ungkapan menurut hubungan antara pemberi dan penerima, yang mana penerima merupakan pihak lawan yang kedudukannya lebih rendah dari dari pada pihak yang memberikan. Contoh :

私は社長におめやげをいただきます

Watashi ha shacho ni omeyage o itadakimasu

Saya mendapat oleh - oleh dari direktur.

私は息子におかしをやります。

Watashi ha musuko ni okashi o yarimashita

Saya memberikan kue kepada anak perempuan saya.

4. Untuk Menyatakan Tujuan

Tujuan dari suatu proses tindakan aktifitas, kata kerja yang diikuti oleh partikel ni. Jadi partikel ni yang berfungsi untuk menyatakan tujuan. Dengan demikian fungsi pemakaian partikel ni diantara dua kata kerja berturut-turut dengan pola verba + ni Verba .Dimana kata kerja I merupakan tujuan dari kata kerja II.

私は家へ昼ご飯を食べに帰ります。

Watashi ha uchi e hirugohan o tabe ni kaerimasu.

Saya pulang ke rumah untuk makan siang

\section{Kesimpulan}

Berdasarkan analisa data dan hasil temuan yang didapat, maka dapat disimpulkan penggunaan partikel ni dalam kalimat bahasa Jepang yaitu, penggunaan partikel ni yang berfungsi untuk menyatakan tempat adalah ditentukan oleh predikatnya. Predikat bisa berupa kata kerja (verba) atau kata benda (nomina) yang bersifat sebagai kata kerja, dan kata kerja tersebut mengandung makna leksikal menempati atau membutuhkan tempat.

Partikel ni berfungsi untuk menyatakan tempat keberadaan suatu benda mati (benda yang tidak bernyawa) atau benda hidup (benda bernyawa). Fungsi partikel ni untuk menyatakan waktu, terjadinya sesuatu perbuatan/ peristiwa atau kegiatan, menyatakan waktu yang pasti ,tertentu dan terperinci.

Untuk menyatakan lawan yaitu seseorang yang menjadi lawan pembicaraan atau perbuatan. Fungsi partikel ni untuk menyatakan tujuan, proses tindakan yang dinyatakan oleh kata kerja yang menjadi predikat dalam suatu kalimat. Menyatakan aktivitas yang dilakukan oleh orang ke dua kepada orang ke satu, yang dilihat dari sudut pandang orang ke satu. 


\section{BIBLIGRAFI}

Aisah, Siti, \& Noviadi, Andri. (2018). Ragam Bahasa Lisan Para Pedagang Buah Pasar Langensari Kota Banjar. Literasi: Jurnal Bahasa Dan Sastra Indonesia Serta Pembelajarannya, 2(1), 81-87.

Aisyah, Nyimas, Kalijaga, Diajukan Kepada Pascasarjana U. I. N. Sunan, \& Guna, Untuk Memenuhi Salah Satu Syarat. (2016). Upaya Guru Dalam Mengembangkan Kreativitas Bahasa Lisan Anak Melalui Metode Bermain Peran Dan Metode Bercerita Di Tk Bhayangkari 23 Bandar Lampung. Darul Ilmi: Jurnal Ilmiah Pendidikan Guru Raudhatul Athfal, 1, 8-33.

Cahyaningrum, Ramadhani Wulan. (2019). Bahasa Indonesia Sebagai Alat Komunikasi Dan Fungsi Teks Dalam Pembelajaran.

Depdikbud. (1990). Kamus Besar Bahasa Indonesia. Jakarta: Balai Pustaka.

Filliyani, Frida. (2003). Dasar-dasar Terjemahan. Jakarta.

Haraha, Risky Anggita, \& Pi, S. (2018). Hakikat Bahasa.

Herniti, Ening. (2010). Bahasa dan Kelahirannya. Adabiyyāt: Jurnal Bahasa Dan Sastra, 9(1), 107-132.

Kartika, Joanna. (2018). perancangan tentang kamus gaul dalam bahasa isyarat. Universitas Multimedia Nusantara.

Ratna, Nyoman Kutha. (2004). Penelitian Sastra: Teori, Metode, dan Teknik. Yogyakarta: Pustaka Pelajar.

Sudjianto. (2000). Gramatika Bahasa Jepang Modern Seri B. Jakarta: Kasaint Blan.

Sudjianto, Press. (1996). Gramatika Bahasa Jepang. Jakarta: Kesaint Blanc.

Surakhmad, Winarno. (1990). Pengantar penelitian ilmiah: dasar, metode dan teknik. Tarsito.

Zellatifanny, Cut Medika, \& Mudjiyanto, Bambang. (2018). Tipe Penelitian Deskripsi dalam Ilmu Komunikasi. Diakom: Jurnal Media Dan Komunikasi, 1(2), 83-90. 